\title{
電動注入器を用いた声帯内脂肪注入術
}

\author{
岡田信也・田村 悦代・福田 宏之*・飯田 政弘
}

\section{Fat Injection with an Electric Injector}

\author{
Shinya Okada, Etsuyo Tamura and Masahiro Iida \\ (Tokai University Hospital) \\ Hiroyuki Fukuda \\ (International University of Health and Welfare, Tokyo Voice Center)
}

\begin{abstract}
Sixteen patients with glottic insufficiency received intra-fold autologous fat injection therapy with an electric injector.

Using the electric injector made minute control possible.

Fourteen of the sixteen patients who had been given the above therapy showed an extended maximum phonation time, which was maintained for about six months after the injection.

We think that using an electric injector facilitates easier and more accurate fat injection.
\end{abstract}

Key words : fat injection, electric injector, glottic insufficiency

\section{はじめに}

声門閉鎖不全疾患に対するリハビリテーションとして 行われてきた声帯内注入術に自家脂肪組織を用いる方法 は，1991 年 Mikaelian ら ${ }^{1)}$ が報告して以来，日本におい ても臨床応用がされてきた ${ }^{2)}$. 注入材料として脂肪組織 を用いる方法に限らず, 注入術の手技は, 一般に簡便で あるといわれているが, 注入の深さ，方向には，十分留 意する必要があることはいうまでもない。つまり，徒手 による注入は，注入時に針先が不安定になりやすいとい われ，針先にストッパーなどを工夫する方法も報告され てきた ${ }^{3)}$. 今回われわれは, 従来の方法であった徒手に よる脂肪注入の手技 ${ }^{4) 5)}$ に, 電動注入器を用いることで, 安定した針の深さを容易に維持することができ, 目標と する部位に正確に脂肪を注入することができたので，そ の方法について術後音声の評価とともに報告する.

\section{対象と方法}

\section{1. 対象}

2003 年 8 月より 2005 年 12 月の間に, 東海大学医学部 付属東京病院耳鼻咽喉科に音声障害を主訴として受診し た症例のうち, 発声時声門閉鎖不全があり, 気息性嗄声 が高度で, 患者本人の希望があった 16 例を対象とした。 内訳は, 片側声帯麻痺は 9 例（特発性 3 例, 食道癌術後 2 例, 甲状腺術後 1 例, 頸部神経鞘腫術後 1 例, 上皮小 体エタノール注入術後 1 例, 頸椎症術後 1 例), 声带溝症 4 例, 外傷 3 例である. 年齢は, 13 歳から 77 歳で, 平均 年齢は 55 歳, 男性 9 例, 女性 7 例であった。

\section{2. 方法}

1）脂肪組織の採取および声帯内注入

全身麻酔下に, 臍下部の皮膚を約 $3 \mathrm{~cm}$ 横切開し, 明視 下に血管, 線維組織を避けながら, 脂肪組織を拇指頭大 切除した。採取した脂肪組織は，線維組織を除去しなが ら小剪刀で 1 $2 \mathrm{~mm}$ 大に細切し, 生理食塩水で洗浄しな 
がら血球成分を取り除いた。細切した脂肪組織を，ディ

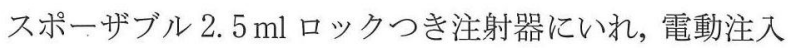
器（MOTER INJECTOR，デントロニクス（株）（図 1) にセットし，喉頭直達鏡用の $28 \mathrm{~cm}, 16 \mathrm{G}$ の注入針を接 続して使用した。

注入は，喉頭顕微鏡下で声帯を観察しながら，経口的 に直接声带内に脂肪を注入した。使用した電動注入器は, 手元のスイッチで，約 $0.06 \mathrm{ml} /$ 分の速度で，脂肪組織を 注入することが可能であった（図 2 )。

片側声帯麻痺症例に対しては，声帯上面外側の仮声帯 直前で膜様部中央よりやや後方に，針を深さ約 $0.5 \mathrm{~mm}$

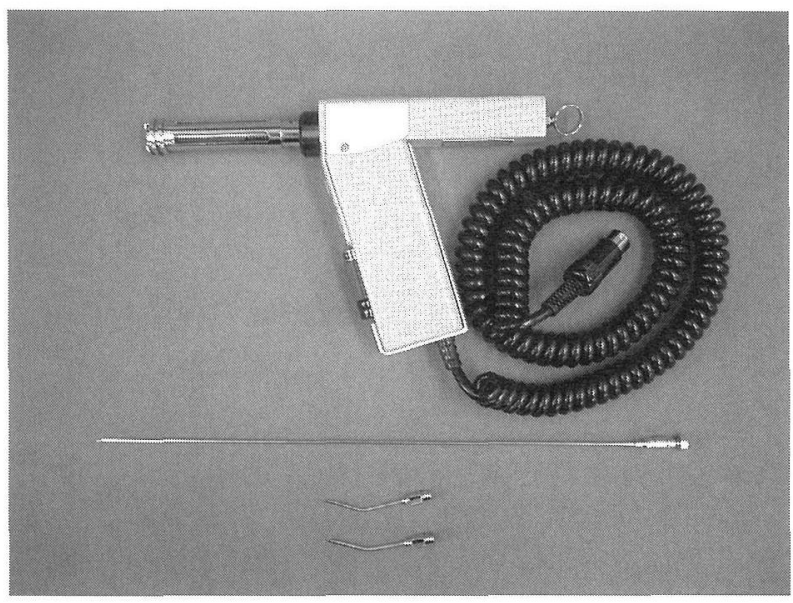

図 1 電動注入器

脂肪組織を入れたディスポーザル注射器をセットして, 注入針を接続してある。

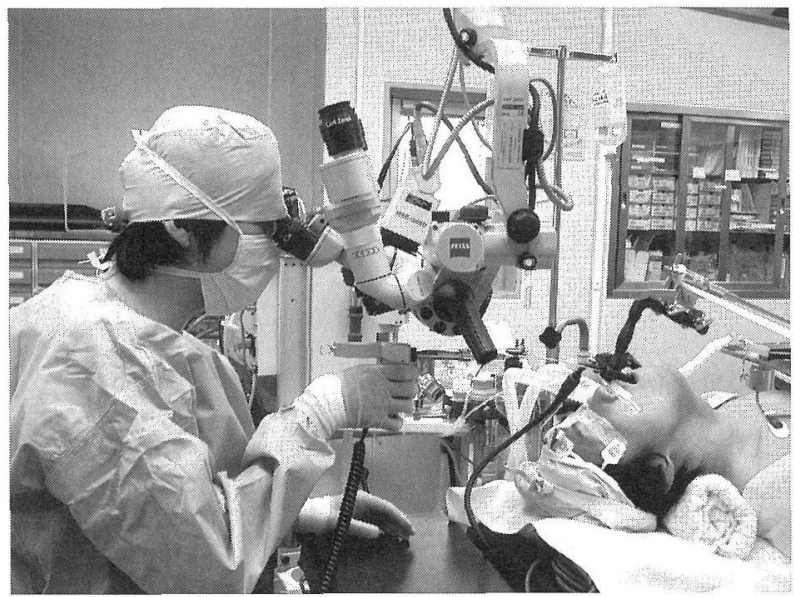

図 2 喉頭直達鏡下脂肪注入術の実際
刺入し，筋層を目標として注入した。注入時，声帯の膨 隆程度を観察し, 注入針の方向や深さを変更させながら， 患側声带膜様部辺縁が，正中よりやや健側一膨隆した状 態になるまで注入した。 また, 声帯溝症や外傷症例では, 粘膜固有層深層を中心に浅層にも注入した。

注入後, 脂肪の逆流を防ぐために，声帯の穿刺孔を人 フィブリノゲン製剤で閉鎖した。声帯内への脂肪の注入 量は $0.5 \sim 3.0 \mathrm{ml}$ で平均 $1.3 \mathrm{ml}$ であった。 なお臍下部の 脂肪採取部は, 止血を確認した後, 縫合し圧迫固定した。

2）音声および喉頭所見の評価

音声は，手術前および術後約 1 力月後，6力月後におけ る，母音「あ」または「え」の最長発声持続時間を測定 した。また，発声時の声帯粘膜波動の状態を経時的に， ストロボスコープを用いて VTR 録画し, 経験ある音声外 科医 2 人と耳鼻咽喉科医 1 人の合計 3 人で評価した。

\section{結果}

喉頭外傷例である症例 6 を除いて, 術後, 全例で発声 時の声門閉鎖が認められ，嗄声や発声時の易疲労感は著 明に改善した。術後に, 音声の悪化を認めた症例はなかっ たが，喉頭外傷症例で，注入時に逆流が多く有効な注入 ができなかった症例 6 では, 音声の改善が得られなかっ た。 また, 声帯溝症症例で, 術後 3 カ月目までは症状が

表 1 声帯内自家脂肪注入術を施行した症例の一覧および注入 後の結果

\begin{tabular}{|c|c|c|c|c|c|}
\hline \multirow{2}{*}{ 症例 } & \multirow{2}{*}{$\begin{array}{l}\text { 年齢 } \\
\text { (歳) }\end{array}$} & \multirow{2}{*}{ 性別 } & \multicolumn{2}{|c|}{ 最長発声持続時間 (秒) } & \multirow{2}{*}{ 疾患名 } \\
\hline & & & 術前 & 術後 3力月 & \\
\hline 1 & 36 & 男 & 3 & 20 & 声带溝症 \\
\hline 2 & 61 & 男 & 11 & 19 & 声帯溝症 \\
\hline 3 & 76 & 女 & 6 & 14 & 声帯溝症 \\
\hline 4 & 25 & 女 & 13 & 12 & 声帯溝症 \\
\hline 5 & 61 & 女 & 13 & 15 & 喉頭外傷 \\
\hline 6 & 61 & 男 & 3 & 3 & 喉頭外傷 \\
\hline 7 & 35 & 男 & 17 & 20 & 喉頭外傷 \\
\hline 8 & 38 & 男 & 2 & 10 & 左声帯麻箄 \\
\hline 9 & 73 & 女 & 4 & 10 & 左声带麻痺 \\
\hline 10 & 13 & 男 & 3 & 15 & 左声帯麻痺 \\
\hline 11 & 71 & 女 & 6 & 10 & 左声帯麻㯅 \\
\hline 12 & 65 & 女 & 3 & 8 & 右声带麻痺 \\
\hline 13 & 67 & 男 & 18 & 26 & 左声帯麻痺 \\
\hline 14 & 77 & 女 & 6 & 17 & 左声帯麻痺 \\
\hline 15 & 76 & 男 & 2 & 7 & 左声帯麻痺 \\
\hline 16 & 45 & 男 & 4 & 16 & 左声帯麻痺 \\
\hline
\end{tabular}




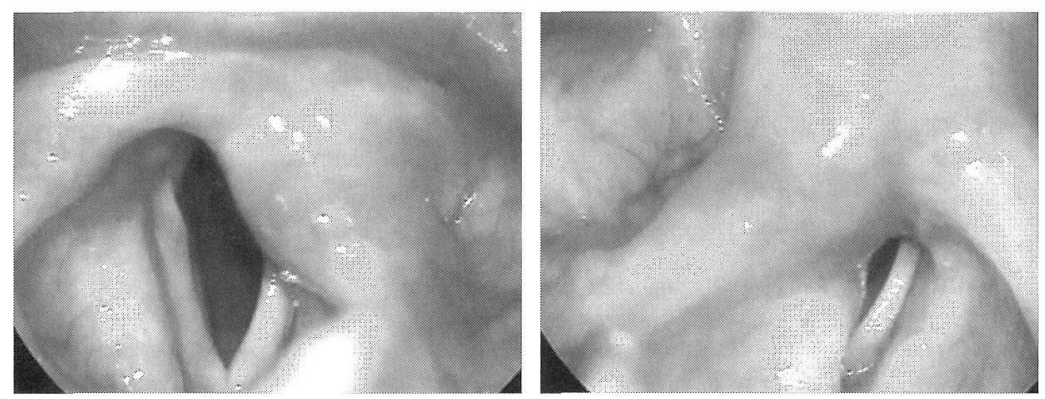

(1)
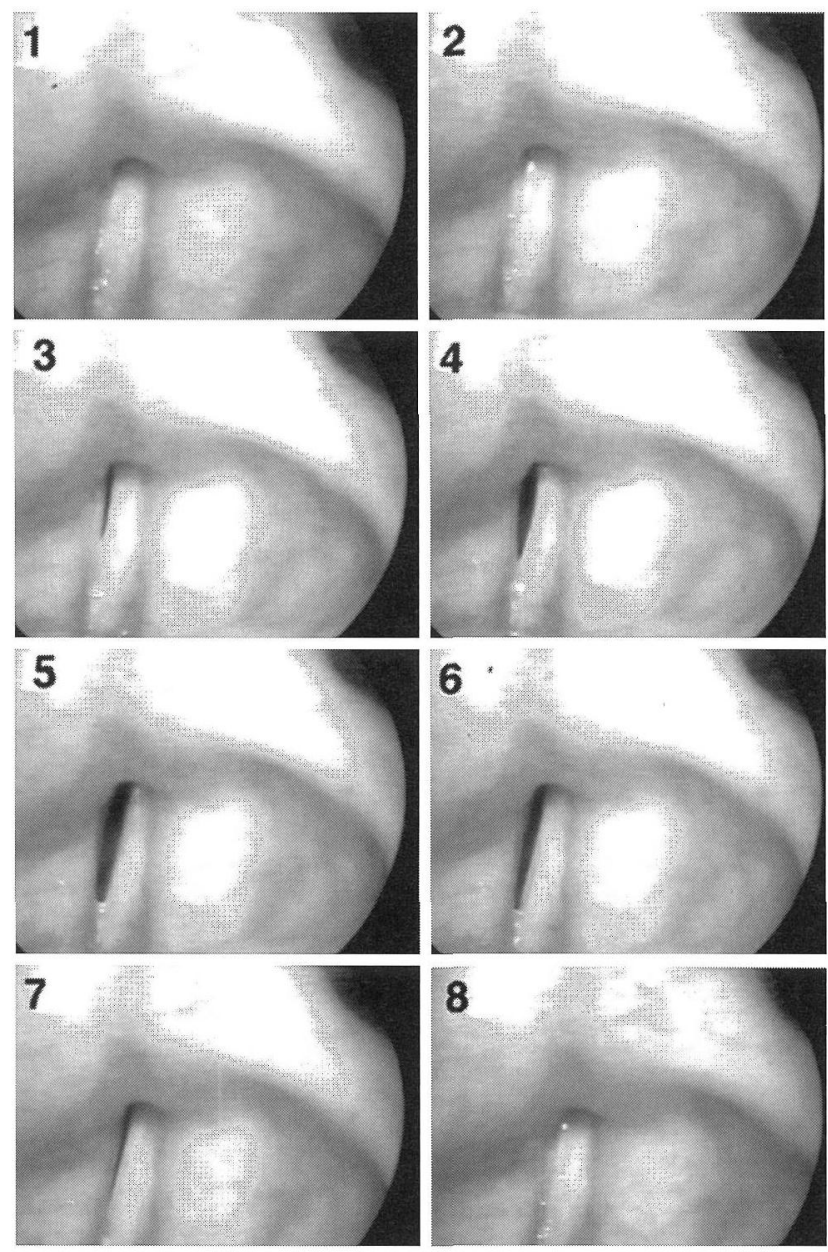

(2)

図 3 術前および術後のストロボスコープ所見

(1)術前：左声帯は，傍正中位に固定し，発声時声門閉鎖がみられなかった。

(2)術後 3力月：発声時，十分な声門閉鎖とともに，左声帯に粘膜波動吕認められた。

改善したが, 声带内注入脂肪が周囲組織に吸収され, 徐々 に術前と同じ状態になってしまった例が 1 例 (症例 4) 認 められた。
術後 6 カ月以上経過した症例の最長発声持続時間は, 16 例中 14 例で, 延長しており, 術前は平均 7.1 秒であった が, 術後 6 力月では平均 14.1 秒と著明に延長した (表 1 )。 
VTRストロボスコピー検查による発声時の声帯粘膜波 動の検討では，声帯内に十分な脂肪が注入できなかった 症例 6 を除き, 注入後は一時的に注入側の粘膜波動が障 害されたが，術後 1 カ月以降は，良好な粘膜波動が観察 された。 なお，術後全例で腹部の脂肪摂取部位に皮下出 血などの合併症はなかった. 以下に代表症例を提示する.

症例 14 は， 77 歳女性. 2004 年 8 月に 1 年 6 力月前加 ら嗄声が出現したとして, 東海大学医学部付属病院耳鼻 咽喉科を受診した。初診時，左声帯は，傍正中位に固定 し発声時声門閉鎖不全が高度であった。精查の結果，声 帯固定の原因疾患を特定できず，特発性左声帯麻痺の診 断にて，2004 年 9 月 13 日，全身麻酔下に下腹部の皮下 脂肪を用いた左声帯内脂肪注入術を当院にて施行した. 細切した脂肪組織を, 電動注入器を用いて, 左声帯筋層 を目標として， $0.5 \mathrm{ml}$ 注入した. 注入術直後より発声時 の声門閉鎖は得られたが, 粘膜波動は認められなかった。 注入 1 カ月後以降は，発声時の粘膜波動が改善し，気息 性嗄声は消失した。図 3 亿術前および術後 1 日目, 術後 3カ月のストロボスコープ所見を示した（図 3).

\section{考 察}

声帯内注入術は，声門閉鎖不全に対して行われてきた リハビリテーション手術であるが，いまだ完成された手 技ではないといわれている6)。つまり，注入材料につい ては主に組織反応の点から多くの検討がされてきたが, 注入手技についての検討は少なく問題点を残していると いえる. 田村ら ${ }^{7)}$ は, 注入部位や注入材料は, 疾患によっ て考慮すべきであると報告している．今回使用した脂肪 組織は，その粘性が粘膜固有層に近似しているといわれ ており ${ }^{8)}$, 粘膜固有層に注入しても粘膜波動を障害しな いと考えられる。したがって，脂肪組織の注入術に㧤い ては，的確な部位へ，容量増量を目的として注入するこ とによって, 症状の改善が得られると考えられる. 今回 われわれが行った電動注入器を用いた注入法は, $0.06 \mathrm{ml} /$ 分の緩徐な一定速度での注入が可能であるた
め, 注入時に周囲組織への広がりが期待でき，注入後の 針穴からの逆流を減少させる効果が期待できる。また， 注入時に不必要な力が針先にかからず，針先を一定の深 さに保持できるといら点や注入中に注入方向を変化させ ることができる点で有用であった。

\section{まとめ}

電動脂肪注入器による声帯内自家脂肪注入術について 報告した．電動注入機は針先が安定するため注入の深さ や注入量などの微細な調節が可能なので，声帯麻痺など の声門閉鎖不全疾患に対する注入術手技の一つとして有 用であると考える。

\section{参考文献}

1) Mikaelian DO, Lowry LD and Sataloff RT : Lipoinjection for unilateral vocal cord paralysis. Laryngoscope 101:465 468, 1991.

2）田村悦代, 北原 哲, 甲能直幸, 他: 声帯内自家脂肪注入 術. 音声言語医 $41: 389 \sim 394 ， 2000$.

3) Rubin $\mathrm{HJ}$ : Intracordal injection of silicone in selected dysphonia. Arch Otolaryngol $75: 604 \sim 607,1965$.

4）鶴田至宏, 長谷川太郎, 清水智之, 他：声帯内脂肪注入術 後の長期観察. 日気管食道会報 $53: 6 \sim 12,2002$.

5）北原 哲, 田村悦代, 古川太一, 他: 声帯内脂肪注入術. 日気管食道会報 $52 ： 264 \sim 269 ， 2001$.

6）高山悦代，福田宏之，川崎順久，他：声帯内注入術につい て一手技および器具に関する検討一。耳鼻と臨 $35: 668$ 672,1989

7）田村悦代，北原 哲：音声から見た声帯内自家組織注入療 法. 音声言語医 $44: 327 \sim 332,2003$.

8) Chan RW and Titze IR : Viscosities of implantable biomaterials in vocal fold augmentation surgery. Laryngoscope 108:725 731, 1998 .

原稿受付：平成18年 6 月 12 日 原稿採択：平成18年10月27日 別刷請求先：岡田信也 テ151-0053 東京都渋谷区代々木1-2-5 東海大学医学部附属東京病院耳鼻咽喉科 